\title{
Sensorless Control of Brushless Doubly-fed Generator Using Luenberger Observer Based Wind Energy Conversion Systems
}

\author{
Hicham Serhoud, Djilani Benattous \\ Department of Electrical Engineering, University of EL-Oued, Algeria
}

\begin{tabular}{l}
\hline \hline Article Info \\
\hline Article history: \\
Received Mar 14, 2018 \\
Revised May 31, 2018 \\
Accepted Jun 6, 2018 \\
\hline
\end{tabular}

\section{Keywords:}

Brushless doubly fed generator (BDFG)

Sensruless control

Luenberger observer

Wind energy conversion systems

\begin{abstract}
This paper investigates the use of Luenberger observer for sensorless power control of brushless double fed induction machine (BDFM) in wind energy conversion systems, the control strategy for flexible power flow control is developed by applying flux-oriented vector control (technique), In order to estimate the rotor speed, an adaptive algorithm based on Lyapunov stability theory will be design. Finally, the analyzed and simulation results in MATLAB/ Simulink platform confirmed the good dynamic performance of this new sensorless control for BDFG based variable speed wind turbines.
\end{abstract}

Copyright (C) 2018 Institute of Advanced Engineering and Science. All rights reserved.

\section{Corresponding Author:}

Hicham Serhoud,

Institute of Science Technology, Department of Electrical Engineering,

University of EL-Oued, Algeria,

BP 476 Gumare, EL-Oued 39400, Algeria.

Email: hserhoud@gmail.com

\section{INTRODUCTION}

In recent years, the electrical machine has expanded considerably with the development of power electronics and data processing, in this way a many researchers developed the difference observation, for estimating the rotor speed and parameters identification of electrical machine. The Brushless double fed induction motor is one of the most important ac machines used because of its low cost and high reliability [1].

Sensorless control has been successfully applied to the BDFG based on an extended Kalman filter observer [2], The rotor speed estimator is designed by a phase locked loop ignoring the power winding resistance [3], and MRAS observer scheme based on the stator current of the control winding (CW) yessed the a phase locked loop (PLL) is proposed by [3].

The Luenberger observer is a well-known method for the sensorless control of cage induction machines, there are few reports related to the use of Luenberger observer for sensorless control of DFIG [4-6], when has been proved to be a good compromise between accuracy and complexity, and is able to work at wide speed range [7].

This paper discussed of a novel sensorless vector control of BDFG using Luenberger observer (LO), the error between the observed value and the true value considered the rotor speed , based on Lypunov's stability theory. General scheme of Luenberger observer is shown in Figure 1. 


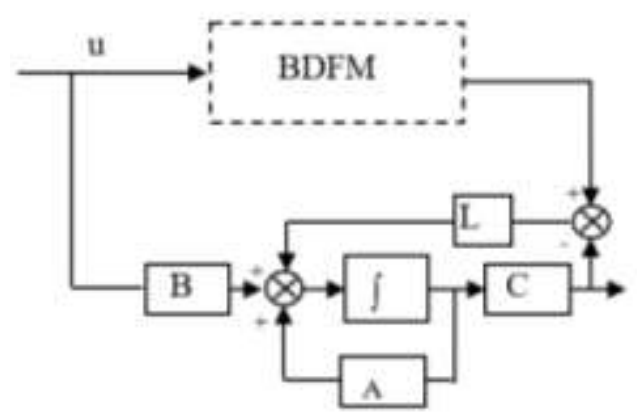

Figure 1. General scheme of Luenberger observer for speed estimation of BDFG

\section{THE MATHEMATICAL MODE OF BDFM} speed equal to:

The BDFM is normally operated in the synchronous mode and the natural synchronous

$$
\omega_{\mathrm{r}}=\frac{\omega_{\mathrm{p}} \pm \omega_{\mathrm{c}}}{\mathrm{p}_{\mathrm{p}}+\mathrm{p}_{\mathrm{c}}}
$$

$\omega_{\mathrm{p}}$ and $\omega_{\mathrm{c}}$ are the angular frequency of power winding and control winding and $\mathrm{Pp}$ and $\mathrm{Pc}$ are the number of pole pairs of power winding and control winding.

The mathematical model of BDFG with d-q reference (PW) is able to be expressed as [1], [8], [9]:

$$
\begin{aligned}
& V_{p}=R_{p} \cdot i_{p}+\frac{d \psi_{p}}{d t}+j \omega_{p} \psi_{p} \\
& V_{c}=R_{c} \cdot i_{c}+\frac{d \psi_{c}}{d t}+j\left(\omega_{p}-\left(P_{p}+P_{c}\right) \omega_{r}\right) \psi_{c} \\
& V_{r}=R_{r} \cdot i_{r}+\frac{d \psi_{r}}{d t}+j\left(\omega_{p}-P_{p} \omega_{r}\right) \psi_{r}
\end{aligned}
$$

And the flux equations are given as:

$$
\begin{aligned}
& \psi_{\mathrm{p}}=\mathrm{L}_{\mathrm{p}} \mathrm{i}_{\mathrm{p}}+\mathrm{M}_{\mathrm{p}} \mathrm{i}_{\mathrm{r}} \\
& \psi_{\mathrm{c}}=\mathrm{L}_{\mathrm{c}} \mathrm{i}_{\mathrm{c}}+\mathrm{M}_{\mathrm{c}} \mathrm{i}_{\mathrm{r}} \\
& \psi_{\mathrm{r}}=\mathrm{L}_{\mathrm{r}} \mathrm{i}_{\mathrm{r}}+\mathrm{M}_{\mathrm{c}} \mathrm{i}_{\mathrm{c}}+\mathrm{M}_{\mathrm{p}} \mathrm{i}_{\mathrm{p}}
\end{aligned}
$$

The electromagnetic torque of BDFG is expressed as [3]:

$$
\mathrm{T}_{\mathrm{e}}=\frac{3}{2} \mathrm{P}_{\mathrm{p}} \mathrm{M}_{\mathrm{p}}\left(\mathrm{i}_{\mathrm{qp}} \mathrm{i}_{\mathrm{dr}}-\mathrm{i}_{\mathrm{dp}} \mathrm{i}_{\mathrm{qr}}\right)-\frac{3}{2} \mathrm{P}_{\mathrm{c}} \mathrm{M}_{\mathrm{c}}\left(\mathrm{i}_{\mathrm{qc}} \mathrm{i}_{\mathrm{dr}}-\mathrm{i}_{\mathrm{dc}} \mathrm{i}_{\mathrm{qr}}\right)
$$

The active and reactive powers of BDFM are as follows:

$$
\begin{aligned}
& \mathrm{P}_{\mathrm{p}}=\frac{3}{2}\left(\mathrm{~V}_{\mathrm{dp}} \mathrm{i}_{\mathrm{dp}}+\mathrm{V}_{\mathrm{qp}} \mathrm{i}_{\mathrm{qp}}\right) \\
& \mathrm{Q}_{\mathrm{p}}=\frac{3}{2}\left(\mathrm{~V}_{\mathrm{qp}} \mathrm{i}_{\mathrm{dp}}-\mathrm{V}_{\mathrm{dp}} \mathrm{i}_{\mathrm{dp}}\right)
\end{aligned}
$$




\section{VECTOR CONTROL DESIGN FOR BDFG}

In this section, the vector control of BDFM will be presented, to achieve regulation of the active and reactive power between the BDFG and the grid [9], [10]. The vector control of BDFM is similar of the principle of classical vector control of DFIM, which it based of annulled the quadrature component of the PW flux, and suppose the $R_{p}$ is neglected, the Equations (2) and (5) can be written as follow:

$$
\begin{aligned}
& \left\{\begin{array}{l}
\mathrm{V}_{\mathrm{dp}}=0 \\
\mathrm{~V}_{\mathrm{qp}}=\mathrm{V}_{\mathrm{P}}=\omega_{\mathrm{p}} \psi_{\mathrm{P}}
\end{array}\right. \\
& \left\{\begin{array}{l}
\psi_{\mathrm{P}}=\mathrm{L}_{\mathrm{p}} \mathrm{i}_{\mathrm{dp}}+\mathrm{M}_{\mathrm{p}} \mathrm{i}_{\mathrm{dr}} \\
0=\mathrm{L}_{\mathrm{p}} \mathrm{i}_{\mathrm{qp}}+\mathrm{M}_{\mathrm{p}} \mathrm{i}_{\mathrm{qr}}
\end{array}\right.
\end{aligned}
$$

The rotor currents can be described using the power stator current:

$$
\left\{\begin{array}{l}
\mathrm{i}_{\mathrm{dr}}=\frac{\psi_{\mathrm{P}}}{\mathrm{M}_{\mathrm{p}}}-\frac{\mathrm{L}_{\mathrm{dp}}}{\mathrm{M}_{\mathrm{p}}} \mathrm{i}_{\mathrm{dp}} \\
\mathrm{i}_{\mathrm{qr}}=-\frac{\mathrm{L}_{\mathrm{qp}}}{\mathrm{M}_{\mathrm{p}}} \mathrm{i}_{\mathrm{qp}}
\end{array}\right.
$$

\subsection{The $P W$ currents regulation}

The mathematical mode of BDFG in the steady state given by [11],

$$
\begin{aligned}
& \left\{\begin{array}{l}
\mathrm{V}_{\mathrm{dp}}=\mathrm{R}_{\mathrm{p}} \cdot \mathrm{i}_{\mathrm{dp}}-\omega_{\mathrm{p}} \cdot \mathrm{L}_{\mathrm{p}} \mathrm{i}_{\mathrm{qp}}-\omega_{\mathrm{p}} \mathrm{M}_{\mathrm{p}} \mathrm{i}_{\mathrm{qr}} \\
\mathrm{V}_{\mathrm{qp}}=\mathrm{R}_{\mathrm{p}} \cdot \mathrm{i}_{\mathrm{qp}}+\omega_{\mathrm{p}} \cdot \mathrm{L}_{\mathrm{p}} \mathrm{i}_{\mathrm{dp}}+\omega_{\mathrm{p}} \mathrm{M}_{\mathrm{p}} \mathrm{i}_{\mathrm{dr}}
\end{array}\right. \\
& \left\{\begin{array}{l}
\frac{\mathrm{s}_{2}}{\mathrm{~s}_{1}} \mathrm{~V}_{\mathrm{dc}}=\frac{\mathrm{s}_{2}}{\mathrm{~s}_{1}} \mathrm{R}_{\mathrm{c}} \cdot \mathrm{i}_{\mathrm{dc}}-\omega_{\mathrm{p}} \mathrm{L}_{\mathrm{c}} \mathrm{i}_{\mathrm{qc}}-\omega_{\mathrm{p}} \mathrm{M}_{\mathrm{c}} \mathrm{i}_{\mathrm{qr}} \\
\frac{\mathrm{s}_{2}}{\mathrm{~s}_{1}} \mathrm{~V}_{\mathrm{qc}}=\frac{\mathrm{s}_{2}}{\mathrm{~s}_{1}} \mathrm{R}_{\mathrm{c}} \cdot \mathrm{i}_{\mathrm{qc}}+\omega_{\mathrm{p}} \mathrm{L}_{\mathrm{c}} \mathrm{i}_{\mathrm{dc}}+\omega_{\mathrm{p}} \mathrm{M}_{\mathrm{c}} \mathrm{i}_{\mathrm{dr}}
\end{array}\right. \\
& \left\{\begin{array}{l}
0=\frac{1}{\mathrm{~s}_{1}} \mathrm{R}_{\mathrm{r}} \mathrm{i}_{\mathrm{dr}}-\omega_{\mathrm{p}} \mathrm{L}_{\mathrm{r}} \mathrm{i}_{\mathrm{qr}}-\omega_{\mathrm{p}} \mathrm{M}_{\mathrm{c}} \mathrm{i}_{\mathrm{qc}}-\omega_{\mathrm{p}} \mathrm{M}_{\mathrm{p}} \mathrm{i}_{\mathrm{qp}} \\
0=\frac{1}{\mathrm{~s}_{1}} \mathrm{R}_{\mathrm{r}} \cdot \mathrm{i}_{\mathrm{qr}}+\omega_{\mathrm{p}} \mathrm{L}_{\mathrm{r}} \mathrm{i}_{\mathrm{dr}}+\omega_{\mathrm{p}} \mathrm{M}_{\mathrm{c}} \mathrm{i}_{\mathrm{dc}}+\omega_{\mathrm{p}} \mathrm{M}_{\mathrm{p}} \mathrm{i}_{\mathrm{dp}}
\end{array}\right.
\end{aligned}
$$

$s_{1}, s_{2}$ are the slips, which can be expressed as:

$$
\mathrm{s}_{1}=\frac{\omega_{\mathrm{p}}-\mathrm{P}_{\mathrm{p}} \omega_{\mathrm{p}}}{\omega_{\mathrm{p}}}, \mathrm{s}_{2}=\frac{\omega_{\mathrm{c}}-\mathrm{P}_{\mathrm{p}} \omega_{\mathrm{p}}}{\omega_{\mathrm{c}}}
$$

Used (14), (15) (16), (11) (13), The control winding can be expressed as :

$$
\begin{aligned}
& i_{d c}=\left(\frac{L_{r} L_{p}-M_{p}}{M_{p} M_{c}}\right) i_{d p}-\frac{\psi_{p} L_{r}}{M_{p} \omega_{p} M_{c}}+\frac{R_{r} L_{p}}{M_{p} M_{c} \omega_{p} s_{1}} i_{q p} \\
& i_{q c}=\left(\frac{L_{r} L_{p}-M_{p}}{M_{p} M_{c}}\right) i_{q p}+\frac{R_{r} \psi_{p}}{M p M_{c} \omega_{p} s_{1}}-\frac{R_{r} L_{p}}{M p M_{c} \omega_{p} s_{1}} i_{d p}
\end{aligned}
$$




\subsection{The $\mathrm{CW}$ currents regulation}

Used the Equations (3), (6), (18), (19), the CW voltage can be regulation by the CW currents as:

$$
\begin{aligned}
& V_{d c}=R_{c} \cdot i_{d c}+\left(L_{c}-\frac{M_{c}^{2}}{L_{r}}\right) \frac{d i_{d c}}{d t}-\frac{M_{c} R_{r} L_{p}}{\omega_{p} L_{r} s_{1} M_{p}} \frac{d i_{q p}}{d t}-\frac{M_{c} M_{p}}{L_{r}} \frac{d i_{d p}}{d t} \\
& +\left(\omega_{\mathrm{p}}-\left(\mathrm{P}_{\mathrm{p}}+\mathrm{P}_{\mathrm{c}}\right) \omega_{\mathrm{r}}\right)\left(\mathrm{L}_{\mathrm{c}} \mathrm{i}_{\mathrm{qc}}+\mathrm{M}_{\mathrm{c}}\left(-\frac{\mathrm{L}_{\mathrm{qp}}}{\mathrm{M}_{\mathrm{pl}}} \mathrm{i}_{\mathrm{qp}}\right)\right) \\
& \mathrm{V}_{\mathrm{qc}}=\mathrm{R}_{\mathrm{c}} \cdot \mathrm{i}_{\mathrm{qc}}+\left(\mathrm{L}_{\mathrm{c}}-\frac{\mathrm{M}_{\mathrm{c}}^{2}}{\mathrm{~L}_{\mathrm{r}}}\right) \frac{\mathrm{di}_{\mathrm{qc}}}{\mathrm{dt}}-\frac{\mathrm{M}_{\mathrm{c}} \mathrm{R}_{\mathrm{r}} \mathrm{L}_{\mathrm{p}}}{\omega_{\mathrm{p}} \mathrm{L}_{\mathrm{r}} \mathrm{s}_{1} \mathrm{M}_{\mathrm{p}}} \frac{\mathrm{di}_{\mathrm{dp}}}{\mathrm{dt}}-\frac{\mathrm{M}_{\mathrm{p}} \mathrm{M}_{\mathrm{c}}}{\mathrm{L}_{\mathrm{r}}} \frac{\mathrm{di}_{\mathrm{qp}}}{\mathrm{dt}} \\
& -\left(\omega_{p}-\left(P_{p}+P_{c}\right) \omega_{r}\right)\left(L_{c} i_{d c}+M_{c}\left(\frac{\psi_{P}}{M_{p}}-\frac{L_{d p}}{M_{p}} i_{d p}\right)\right)
\end{aligned}
$$

The third term: $-\left(\omega_{p}-\left(P_{p}+P_{c}\right) \omega_{r}\right)\left(L_{c} i_{d c}+M_{c}\left(\frac{\psi_{p}}{M_{p}}-\frac{L_{p}}{M_{p}} i_{d p}\right)\right)$ Shows another cross and the general block control diagram is shown in Figure 2.

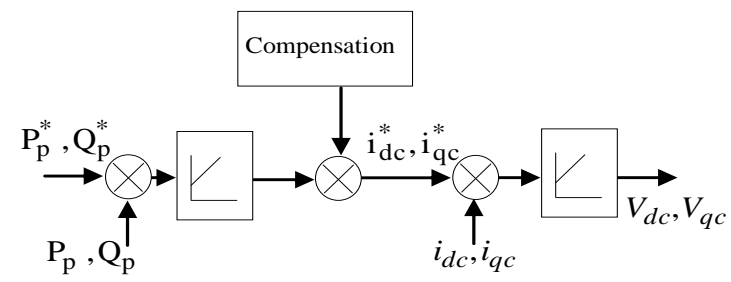

Figure 2. Control scheme for BDFM

\section{THE LUENBERGER OBSERVER}

Using the six-order model of the Brushless doubly-fed induction machine in fixed stator d-q axis reference frame with PW current, $\mathrm{CW}$ current and rotor current components as state variables.

The dynamic model of the BDFM is given in $(d-q)$ reference frame that is used in LO for state observation, the model is given [12-18]:

$$
\begin{aligned}
& \left\{\begin{array}{l}
\mathrm{X}=\mathrm{AX}+\mathrm{Bu} \\
\mathrm{Y}=\mathrm{CX}
\end{array}\right. \\
& \mathrm{u}=\left[\begin{array}{llllll}
\mathrm{V}_{\mathrm{pd}} & \mathrm{V}_{\mathrm{pq}} & \mathrm{V}_{\mathrm{cd}} & \mathrm{V}_{\mathrm{cq}} & 0 & 0
\end{array}\right]^{\mathrm{T}}
\end{aligned}
$$

The state vector is

$$
X=\left[\begin{array}{llllll}
i_{p d} & i_{p q} & i_{c d} & i_{c q} & i_{r d} & i_{r q}
\end{array}\right]^{T}
$$

The system matrix A, the input matrix $\mathrm{B}$ and the output matrix $\mathrm{C}$ are given as:

$$
\mathrm{C}=\left[\begin{array}{ll}
1 & 0 \\
0 & 1 \\
0 & 0 \\
0 & 0 \\
0 & 0 \\
0 & 0
\end{array}\right], \mathrm{B}=[\operatorname{inv}(\mathrm{AL})], \mathrm{A}=[-\operatorname{inv}(\mathrm{AL}) \mathrm{AR}]
$$


Where:

$$
\begin{array}{r}
\mathrm{AL}=\left[\begin{array}{cccccc}
\mathrm{L}_{\mathrm{p}} & 0 & 0 & 0 & \mathrm{M}_{\mathrm{p}} & 0 \\
0 & \mathrm{~L}_{\mathrm{p}} & 0 & 0 & 0 & \mathrm{M}_{\mathrm{p}} \\
0 & 0 & \mathrm{~L}_{\mathrm{c}} & 0 & \mathrm{M}_{\mathrm{c}} & 0 \\
0 & 0 & 0 & \mathrm{~L}_{\mathrm{c}} & 0 & \mathrm{M}_{\mathrm{c}} \\
\mathrm{M}_{\mathrm{p}} & 0 & \mathrm{M}_{\mathrm{c}} & 0 & \mathrm{~L}_{\mathrm{r}} & 0 \\
0 & \mathrm{M}_{\mathrm{p}} & 0 & \mathrm{M}_{\mathrm{c}} & 0 & \mathrm{~L}_{\mathrm{r}}
\end{array}\right.
\end{array}
$$$$
\mathrm{AR}=\left[\begin{array}{lllllll}
\mathrm{R}_{\mathrm{p}} & -\omega_{\mathrm{p}} \mathrm{L}_{\mathrm{p}} & 0 & 0 & 0 & -\omega_{\mathrm{p}} \mathrm{M}_{\mathrm{p}}
\end{array}\right.
$$$$
\begin{array}{llllll}
\omega_{\mathrm{p}} \mathrm{L}_{\mathrm{p}} & \mathrm{R}_{\mathrm{p}} & 0 & 0 & \omega_{\mathrm{p}} \mathrm{M}_{\mathrm{p}} & 0
\end{array}
$$$$
\begin{array}{llllll}
0 & 0 & \mathrm{R}_{\mathrm{c}} & -\omega_{2} \mathrm{Lc} & 0 & -\omega_{2} \mathrm{M}_{\mathrm{c}}
\end{array}
$$$$
\begin{array}{llllll}
0 & 0 & \omega_{2} \mathrm{~L}_{\mathrm{c}} & \mathrm{R}_{\mathrm{c}} & \omega_{2} \mathrm{M}_{\mathrm{c}} & 0
\end{array}
$$$$
\begin{array}{llllll}
0 & -\omega_{3} M_{\mathrm{p}} & 0 & -\omega_{3} \mathrm{M}_{\mathrm{c}} & \mathrm{R}_{\mathrm{r}} & -\omega_{3} \mathrm{~L}_{\mathrm{r}}
\end{array}
$$$$
\left.\begin{array}{llllll}
\omega_{3} \mathrm{M}_{\mathrm{p}} & 0 & \omega_{3} \mathrm{M}_{\mathrm{c}} & 0 & \omega_{3} \mathrm{~L}_{\mathrm{r}} & \mathrm{R}_{\mathrm{r}}
\end{array}\right]
$$

Where:

$$
\begin{aligned}
& \omega_{2}=\omega_{\mathrm{p}}-\left(\mathrm{P}_{\mathrm{p}}+\mathrm{P}_{\mathrm{c}}\right) \omega_{\mathrm{r}} \\
& \omega_{3}=\omega_{\mathrm{p}}-\mathrm{P}_{\mathrm{p}} \omega_{\mathrm{r}}
\end{aligned}
$$

The Luenberger observer which estimates the all stator currents will be designed using the BDFM model.

$$
\hat{\mathrm{X}}=\mathrm{A} \hat{\mathrm{X}}+\mathrm{BU}+\mathrm{L}(\mathrm{Y}-\mathrm{C} \hat{\mathrm{X}})
$$

$\mathrm{L}$ : is the observer gain matrix

$$
\dot{\hat{X}}=(\mathrm{A}-\mathrm{LC}) \hat{\mathrm{X}}+\mathrm{BU}+\mathrm{LY}
$$

The Luenberger matrix gain $\mathrm{L}$ is chosen so that the poles of the characteristic matrix $\mathrm{AL}=\mathrm{A}+\mathrm{LC}$ to be stable. So, all eigenvalues of AL should have negative real parts.

The poles can be placed by solving the differential equation, thus the matrix gain $\mathrm{L}$ can be calculated by the function (PLACE) Pole placement technique in MATLB.

\subsection{Estimation of the rotor speed}

The estimation error of the state variable giving by:

$$
\dot{\mathrm{E}}=(\mathrm{A}-\mathrm{LC}) \mathrm{E}+\Delta \mathrm{A} \hat{\mathrm{X}}
$$

$\Delta \mathrm{A}$ is the error between the two matrices as being exclusively caused by the error between the real and the estimated speed

$$
\Delta \mathrm{A}=(\mathrm{A}-\hat{\mathrm{A}})
$$

Assuming that $\Delta \omega r=\omega r-\hat{r}$ 


$$
\Delta \mathrm{A}=\Delta \omega \mathrm{r}\left[\begin{array}{lllllrrr}
0 & -\mathrm{a} 1 & 0 & \mathrm{a} 2 & 0 & \mathrm{a} 3 \\
\mathrm{a} 1 & 0 & -\mathrm{a} 2 & 0 & -\mathrm{a} 3 & 0 \\
0 & -\mathrm{a} 4 & 0 & \mathrm{a} 5 & 0 & \mathrm{a} 6 \\
\mathrm{a} 4 & 0 & -\mathrm{a} 5 & 0 & -\mathrm{a} 6 & 0 \\
0 & \mathrm{a} 7 & 0 & -\mathrm{a} 8 & 0 & \mathrm{a} 9 \\
-\mathrm{a} 7 & 0 & \mathrm{a} 8 & 0 & -\mathrm{a} 9 & 0
\end{array}\right]
$$

The elements of matric are showed in the appendix.

The speed observer can be constructed based on Lyapunov's stability theory.

Assuming that the Lyapunov function is defined as:

$$
\mathrm{V}=\mathrm{E}^{\mathrm{T}} \mathrm{E}+\frac{1}{\mathrm{~kL}} \Delta \omega \mathrm{r}^{2}
$$

Where:

$$
E=\left[\begin{array}{c}
i_{p d}-i_{p d} \\
i_{d p d}-i_{p d} \\
0 \\
0 \\
0 \\
0
\end{array}\right],
$$

Where $\mathrm{kL}$ is a positive constant, Assuming that $\Delta \omega \mathrm{r}=\omega \mathrm{r}-\omega \mathrm{r}$

The application of the general adaptation mechanism

$$
\hat{\omega r}=k \int E^{T} \Delta A \hat{X} d t
$$

Where:

$$
\hat{\omega r}=k \int e_{p d}\left(-a 1 \hat{i_{p q}}+a 2 \hat{i_{c q}}+a 3 \hat{i_{r q}}\right)+e_{p q}\left(a 1 \hat{i_{p d}}-a 2 \hat{i_{c d}}-a 3 \hat{i_{r d}}\right) d t
$$

Which means:

$$
\hat{\omega r}=k \int a 2\left(e_{p d} \hat{i_{c q}}-e_{p q} \hat{i_{c d}}\right)+a 1\left(e_{p q} \hat{i_{p d}}-e_{p d} \hat{i_{p q}}\right)+a 3\left(e_{p d} \hat{i_{r q}}-e_{p q} \hat{i_{r d}}\right) d t
$$

We can neglect the values of $-\mathrm{a} 1, \mathrm{a} 3$ because its low values compared to $\mathrm{a} 2$, the adaptation mechanism becomes:

$$
\hat{\omega r}=k \int a 2\left(e_{p d} \hat{i_{c q}}-e_{p q} \hat{i_{c d}}\right) d t
$$

Where $\mathrm{k}$ is a positive constant.

Usually the following proportional and integral adaptation mechanism, in order to improve the response of the rotor speed estimation.

$$
\hat{\omega r}=K p\left(e_{p d} i_{c q}-e_{c q} \hat{i}_{c d}\right)+K i \int\left(e_{p d} \hat{i}_{c q}-e_{c q} \hat{i}_{c d}\right)
$$

\section{WIND TURBINE MODEL} derived as:

In this work a horizontal axis wind turbine is used, which the mechanical power of the wind can be 


$$
\mathrm{P}=\frac{\pi}{2} \mathrm{C}_{\mathrm{p}} \mathrm{R}^{2} \rho v^{3}
$$

Where $\rho=$ air density, $R=$ radius of Blades, $v=$ wind speed and $C_{p}=$ power coefficient which can be derived as:

$$
\mathrm{C}_{\mathrm{p}}(\lambda, \beta)=0.5176\left(\frac{116}{\lambda_{\mathrm{i}}}-0.4 \beta-5\right) \mathrm{e}^{-\frac{21}{\lambda_{\mathrm{i}}}}+0.0068 \lambda
$$

Where:

$$
\frac{1}{\lambda_{\mathrm{i}}}=\frac{1}{\lambda+0.08 \beta}-\frac{0.035}{\beta^{3}+1}
$$

The power conversion coefficient defined as:

$$
\lambda=\frac{\omega_{\mathrm{t}} \mathrm{R}}{v}
$$

Where $\omega_{\mathrm{t}}=$ the turbine rotor speed.

The wind turbine is normally characterized between $\mathrm{Cp}$ and $\gamma$ for the given values of pitch angle $\left(\beta^{\circ}\right)$ is as illustrated in Figure 3.

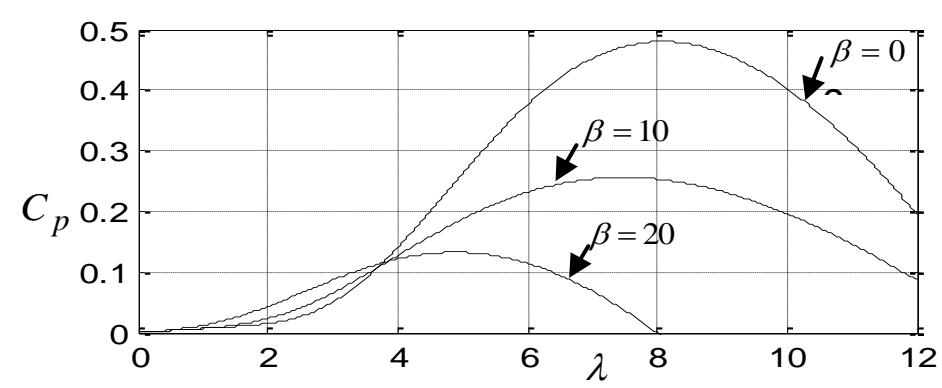

Figure 3. Wind turbine generator $\mathrm{C}_{\mathrm{p}}-\lambda$ characteristics

\subsection{Pitch angle controller design}

The advantage of pitch angle control is mor efficiency in low wind, small variation in the pitch angle can give strongly influenced by of the blade respect to the direction of the wind or to the plane of rotation.

Used the wind velocity $v$, the reference rotor speed for extracting the MPPT is obtained by:

$$
\omega_{\mathrm{m}}=\frac{\mathrm{G} \lambda_{\mathrm{opt}^{\nu}}}{\mathrm{R}}
$$

The gearboxes in a typical wind turbine increase the speed of the generator by the relation

$$
\omega_{\mathrm{m}}=\mathrm{G} \omega_{\mathrm{t}}
$$

The pitch controller is employed to regulation the rotor speed at the maximum used the rotor speed measure and the reference speed, which can find by the Equation (36).

A simple proportional-integral (PI) controller is used to regulation, this regulator followed by limitation to fixing the angle to between the maximum and the minimum angle as shown in Figure 4. 


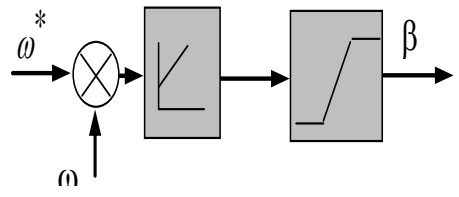

Figure 4. Pitch angle controller

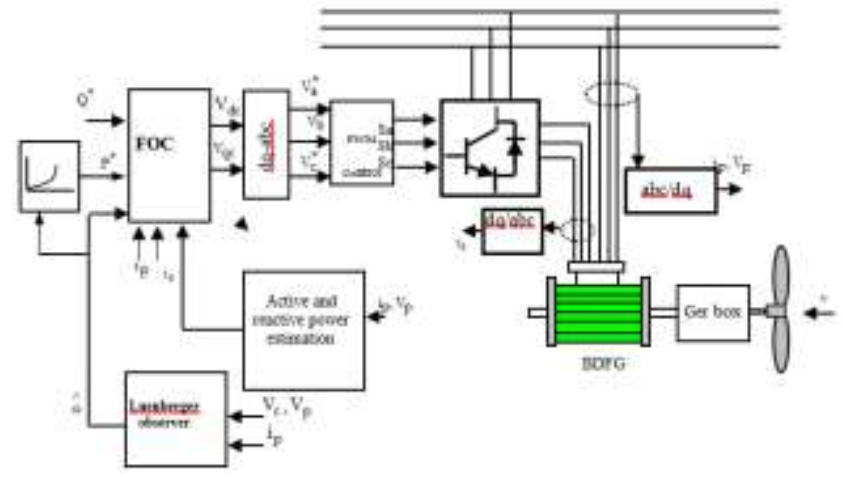

Figure 5. Sensorless vector control of the BDFM using Luenberger observer

\section{SIMULATION RESULTS}

The senseless control developed has been implemented in a MATLB 7.0/simulation, The BDFM used in this simulation model is $3 \mathrm{Y}-3 \mathrm{Y}$ connected and its stator winding is 2-6 poles. The machine parameters presented by J. Poza [3] are used in this simulation as showed in table 1.

To verify the state estimation performance extensive simulation tests were carried out to compare the sensouless control under different wind speed.

A step change in wind speed is simulated in Figure 6, the wind speed is start at $5 \mathrm{~m} / \mathrm{S}$, at 7 second, the wind speed suddenly become $7 \mathrm{~m} / \mathrm{S}$.

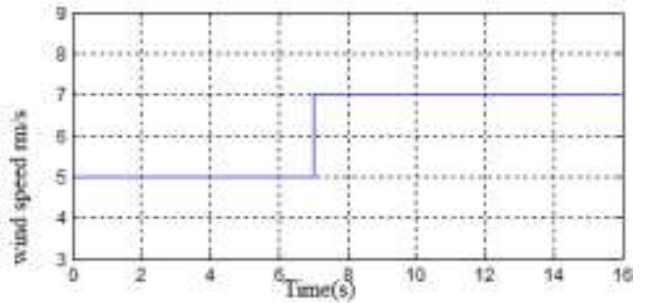

Figure 6. Wind speed

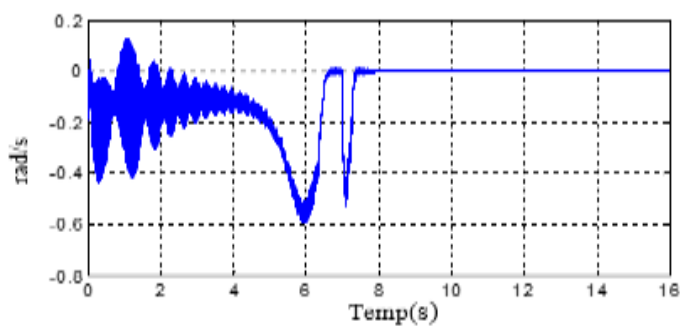

Figure 8. Error of rotor speed

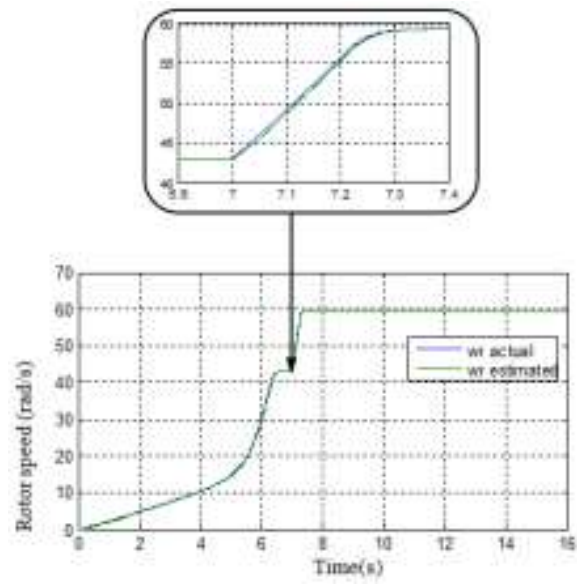

Figure 7. Zoom of actual and estimated rotor speed

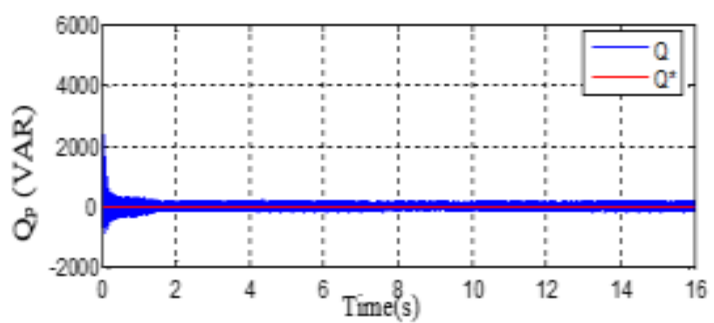

Figure 9. Power winding reactive power 


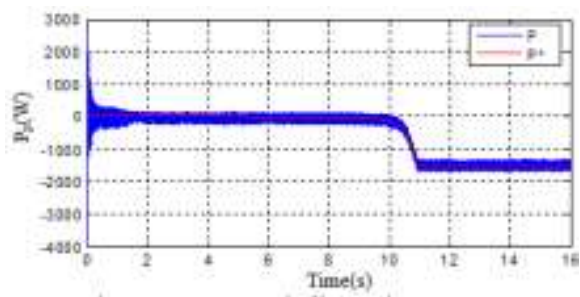

Figure 10. Power winding active power

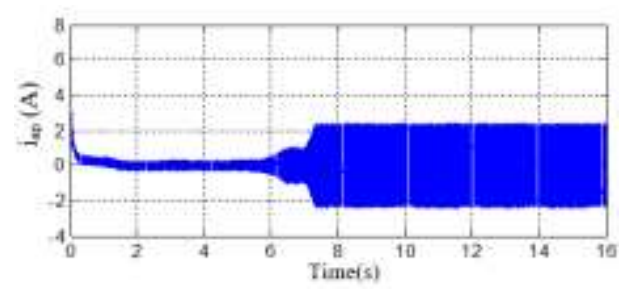

Figure 12. Phase power winding current

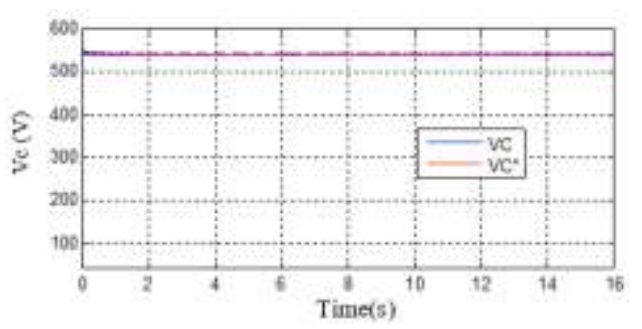

Figure 14. DC voltage

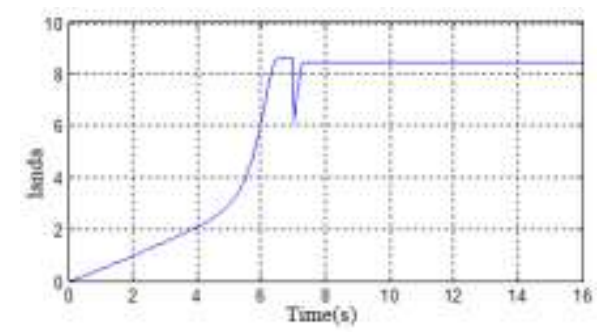

Figure 16. Power coefficient $\mathrm{Cp}$ variation

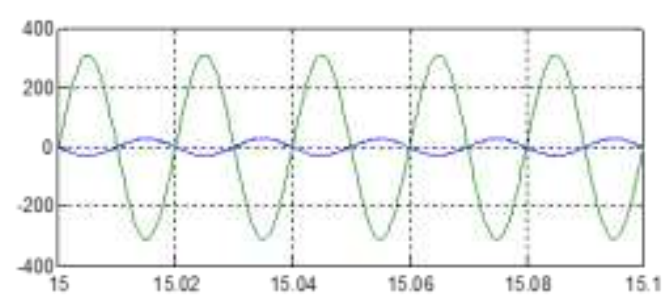

Figure 18. Zoom of phase PW current and voltage

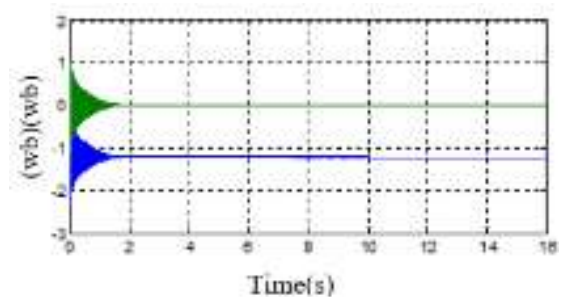

Figure 11. Phase power winding current

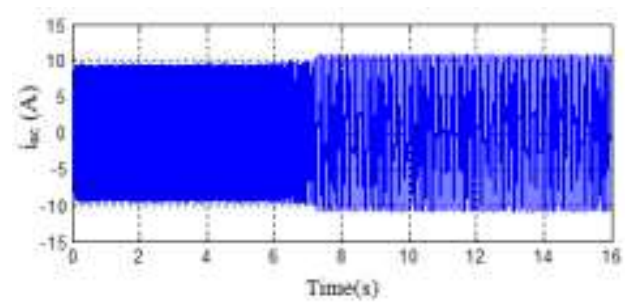

Figure13. Phase control winding current

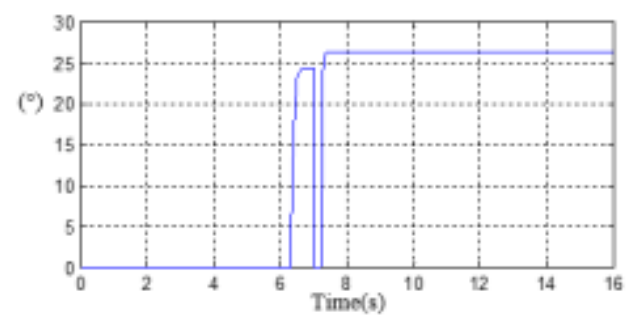

Figure 15. Blade pitch angle

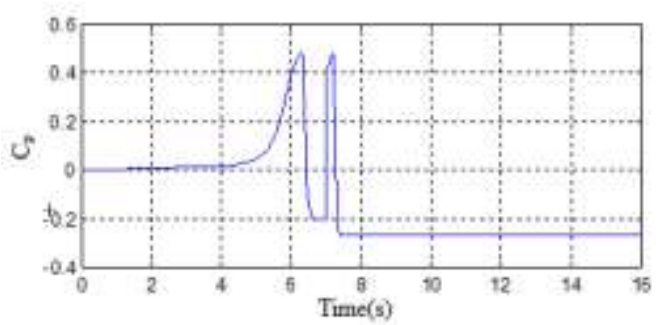

Figure 17. Power coefficient $\mathrm{Cp}$ variation

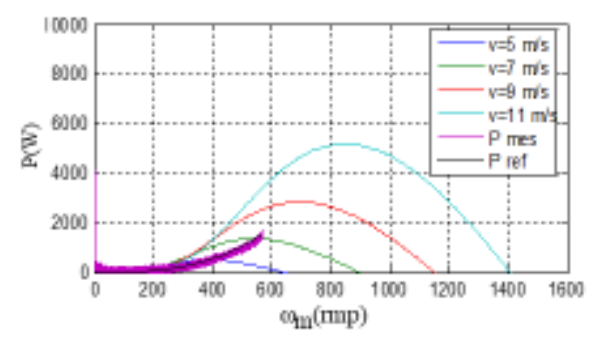

Figure 19. Power coefficient $\mathrm{Cp}$ variation 


\section{CONCLUSION}

In this study we presented in detail sensorless control strategy for (BDFG) in variable speed wind turbine generators used Luenberger observer, a vector control strategy using power winding flux-oriented scheme is proposed to assess the decoupage of active and the reactive power, the observer gains are selected by the pole placement method and the stability of the observer is analyzed using the Lyapunov theory.

The simulation results show effectiveness of the optimal power sensorless operating methods in low and high wind speed, we can conclude the MPPT senseless operating methods proposed only by measuring phase voltages and currents therefore it can improve the control system dependability and energy conversion competence efficiency.

\section{Appendix}

Table 1 The Electrical Parameter of BDFG

\begin{tabular}{cccc}
\hline & $\mathrm{PW}$ & $\mathrm{CW}$ & Rotor \\
\hline Resistance $(\Omega)$ & $\mathrm{R}_{\mathrm{p}}=1.732$ & $\mathrm{R}_{\mathrm{c}}=1.079$ & $\mathrm{R}_{\mathrm{r}}=0.473$ \\
self-inductance $(\mathrm{mH})$ & $\mathrm{L}_{\mathrm{p}}=714.8$ & $\mathrm{~L}_{\mathrm{c}}=121.7$ & $\mathrm{~L}_{\mathrm{r}}=132.6$ \\
Mutual inductance $(\mathrm{mH})$ & $\mathrm{M}_{\mathrm{p}}=242.1$ & $\mathrm{M}_{\mathrm{c}}=59.8$ & \\
\hline
\end{tabular}

\section{REFERENCES}

[1] J. Poza, E. Oarbide, D. Roye and I. Sarasola, "Stability analysis of a BDFM under open-loop voltage control," 2005 European Conference on Power Electronics and Applications, Dresden, 2005, pp. 10 pp.-P.10.

[2] Serhoud, Hicham et Benattous, Djilani, "Sensorless optimal power control of brushless doubly-fed machine in wind power generator based on extended kalman filter," International Journal of System Assurance Engineering and Management, 2013, vol. 4, no 1, p. 57-66.

[3] G. Zhang, J. Yang, M. Su, W. Tang and F. Blaabjerg, "Stator-current-based MRAS observer for the sensorless control of the brushless doubly-fed induction machine," 2017 IEEE Applied Power Electronics Conference and Exposition (APEC), Tampa, FL, 2017, pp. 3150-3155.

[4] L. M. Ying, X. Cui, Q. F. Liao, C. h. Tang, L. C. Le and Z. Chen, "Stator Flux Observation and Speed Estimation of a Doubly Fed Induction Generator," 2006 International Conference on Power System Technology, Chongqing, 2006, pp. 1-6.

[5] S. Thomsen, K. Rothenhagen and F. W. Fuchs, "Analysis of stator voltage observers for a doubly fed induction generator," 2007 European Conference on Power Electronics and Applications, Aalborg, 2007, pp. 1-9.

[6] D. G. Forchetti, G. O. Garcia and M. I. Valla, "Sensorless control of stand-alone Doubly Fed induction generator with an adaptive observer," 2008 IEEE International Symposium on Industrial Electronics, Cambridge, 2008, pp. 2444-2449.

[7] T. Du and M. A. Brdys, "Shaft speed, load torque and rotor flux estimation of induction motor drive using an extended Luenberger observer," 1993 Sixth International Conference on Electrical Machines and Drives (Conf. Publ. No. 376), Oxford, UK, 1993, pp. 179-184.

[8] Serhoud, Hicham. Contribution à la Commande Robuste de la Machine Asynchrone sans Balais à Double Alimentations. 2015. Thèse de doctorat. Université Mohamed Khider-Biskra.

[9] S. Shao, Teng Long, E. Abdi, R. McMahon and Yunxiang Wu, "Symmetrical Low Voltage Ride-Through of the Brushless Doubly-Fed Induction Generator," IECON 2011 - 37th Annual Conference of the IEEE Industrial Electronics Society, Melbourne, VIC, 2011, pp. 3209-3214.

[10] Manel, Jebali-Ben Ghorbal, Jihen, Arbi, et Ilhem, Slama-Belkhodja. A novel approach of direct active and reactive power control allowing the connection of the DFIG to the grid. In : Power Electronics and Applications, 2009. EPE'09. 13th European Conference on. IEEE, 2009. p. 1-10.

[11] Cardenas, Roberto, Pena, Ruben, Proboste, Jose, et al. MRAS observer for sensorless control of standalone doubly fed induction generators. IEEE Transactions on Energy conversion, 2005, vol. 20, no 4, p. 710-718.

[12] G. Liu, S. Wang and R. Zhang, "Modeling and Control of BDFG-based Wind Power Generation Systems under Grid Voltage Sag," 2009 Asia-Pacific Power and Energy Engineering Conference, Wuhan, 2009, pp. 1-5.

[13] Y. Luo and C. Lin, "Fuzzy MRAS based speed estimation for sensorless stator field oriented controlled induction motor drive," 2010 International Symposium on Computer, Communication, Control and Automation (3CA), Tainan, 2010, pp. 152-155.

[14] M. Comanescu and L. Xu, "Sliding-mode MRAS speed estimators for sensorless vector control of induction Machine," in IEEE Transactions on Industrial Electronics, vol. 53, no. 1, pp. 146-153, Feb. 2006.

[15] S. Wang and Z. Lu, "Study on wide range robust speed sensorless control of medium voltage induction motor," 2010 Twenty-Fifth Annual IEEE Applied Power Electronics Conference and Exposition (APEC), Palm Springs, CA, 2010, pp. 1542-1546.

[16] T. Du and M. A. Brdys, "Implementation of extended Luenberger observers for joint state and parameter estimation of PWM induction motor drive," 1993 Fifth European Conference on Power Electronics and Applications, Brighton, UK, 1993, pp. 439-444 vol.4. 
[17] Yunguo Zhu, Xing Zhang, Chun Liu and Hongbing Chen, "Study on speed sensorless control of Brushless DoublyFed wind power generator based on flux linkage of the power winding," Proceedings of The 7th International Power Electronics and Motion Control Conference, Harbin, 2012, pp. 2453-2456.

[18] T. M. Chikouche, A. Mezouar, T. Terras and S. Hadjeri, "Sensorless nonlinear control of a doubly fed induction motor using Luenberger observer," 2015 4th International Conference on Electrical Engineering (ICEE), Boumerdes, 2015, pp. 1-7.

\section{BIOGRAPHIES OF AUTHORS}

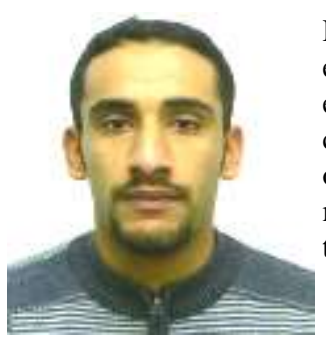

Hicham Serhoud was born on Mar. 30, 1983 in El Oued Algeria. He received Master's degree in electrical engineering from Batna University, Algeria, in 2009. He received the $\mathrm{PhD}$ degree in electrical engineering from Mohamed Kheider University of Biskra (Algeria), in 2015. He is currently associate professor at El Oued University Algeria in Electrical Engineering. His fields of interest are control of Brushless doubly fed induction machines, and double fed induction machines, modelling and control of wind turbines, sensorless control of electrical machine and the control technology of photovoltaic system.

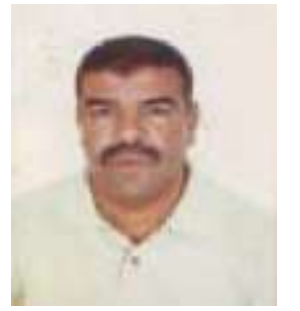

Djilani Benattous was born on May 24, 1959 in El Oued Algeria. He received his Engineer degree in Electrotechnics from Polytechnic National Institute Algiers Algeria in 1984. He got Msc degree in Power Systems from UMIST England in 1987. In 2000, he received his doctorat d'état (PHD from Batna university Algeria). He is currently associate professor at El Oued university Algeria in Electrical Engineering. His research interests in Planning and Economic of Electric Energy System, Optimization Theory and its applications and he also investigated questions related with Electrical Drives and Process Control. 